\title{
GRUNTS STIPRINĀŠANA AR ELEKTROOSMOTISKĀS METODES PALIDDZIB̈U
}

\author{
AIGARS METLĀNS, \\ AINARS SKABS, \\ EDMUNDS TEIRUMNIEKS, \\ GUNDARS VAL,GIS \\ Rēzeknes Augstskola \\ Atbrīvošanas al. 76, Rēzekne, Latvija, LV - 4600
}

Daudzos gadijumos nepietiekoši nostiprinātas grunts dēl notiek nogruvumi, kuri izraisa ēku, būvju daḷēju vai pilnīgu sagraušanu. Šĩ problēma pastāvēja jau ḷoti sen, bet asāk tā sāka izpausties tieši mūsu gadsimtā, sakarā ar ļoti straujo industrializāciju, kurai vajag gan daudz būvmateriālu, tădējādi izveidojas karjeri, gan arī nostiprināt tās platības, uz kurām tiks veikta ēku celtniecība.

Lai gan pastāv l̦oti daudzas grunts nostiprināšanas metodes, savā darbā mēs apskatijām tikai vienu - grunts masiva nostiprināšanas metodi ar elektroosmozes palīdzību, kurai tika veikti arī praktiskie eksperimenti. Metode balstās uz elektriskās strāvas izmantošanu grunts stiprināšanai, tas ir, uz to, ka ūdens virzās no pozitĩvā elektroda uz negatīvo elektrodu, papildus veicot ūdens atsüknēšanu no šĩ elektroda.

Elektroosmoze - tā ir šķīiuma kustība attiecỉbā pret cietu sienu, elektropotenciālu starpības ietekmē jeb šeit šķidrums pārvietojas cietā vidē.

Pētijumi tika veikti laboratorijas apstākḷıs, kā pētāmo mteriālu izmantojot māla un smilts maisijumu dažādās sajaukšanas attiecỉbas. Par sprieguma avotu tika izmantoti divi $12 \mathrm{~V}$ akumulatori, lìdz ar to pētīt varēja paraugus maksimālais pie $24 \mathrm{~V}$ sprieguma. Tika sagatavots paraugs, kuru iepildịja trijās vienāda izmēra kastītēs. Divas no šìm kastītēm pieslēdza pie strāvas avota, bet vienu salīdzināšanai atstāja bez strāvas pieslēguma. Vienai no kastītēm tika pieslēgti plates elektrodi, otrai - parasti drāts veida elektrodi (skat.1.zīmējumu). Eksperimentos konstatēts, ka šķīiums plūst no pozitivi lādētā elektroda uz negatīvo, tātad nostiprinās grunts ap pozitīvo elektrodu.
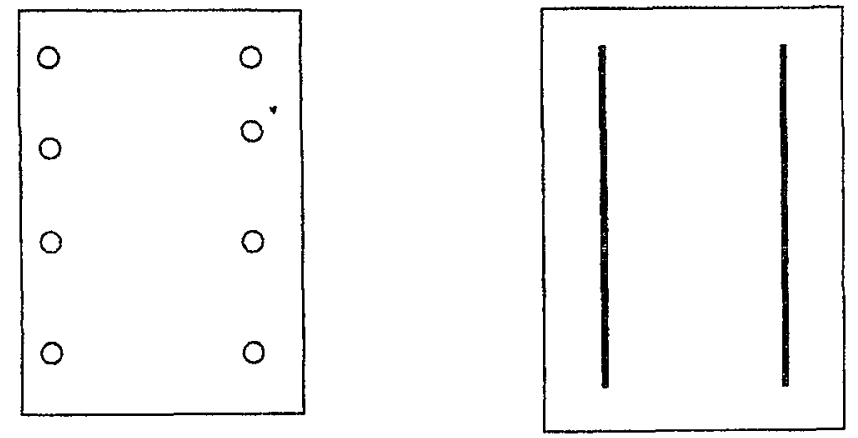

1.zīmējums. Drāts veida un plakanā elektroda izvietojums.

Pirmais eksperiments: Spriegums $24 \mathrm{~V}$, attālums starp drāts veida un plakanajiem elektrodiem $2,5 \mathrm{~cm} .2$ daļas māla, viena daļa smilšu. Eksperimenta ilgums 24 stundas. Jau 
pirmajās minūtēs bija novērojams, kā notiek ūdens parādī̌̌anăs pie negatīvā elektroda. Eksperimentu beidzot negativāa elektroda pusē paraugs vēl bija mitrs, bet pozitīvajā sacietējis rādiusā $2 \mathrm{~cm}$. Tomēr plakanajiem elektrodiem grunts bija mỉkstāka, nekā pie drāts elektrodiem. Paraugā bez elektrodiem pa šo laiku nebija notikušas būtiskas izmaiñas. Lai salīdzinātu, cik daudz üdens ir katrā paraugā tie tika nosvērti, izžāvēti un vēlreiz nosvërti (paraugos, kuros bija elektrodi, svërta tika sacietējusī daḷa ap pozitīvo elektrodu). Rezultāti parādīti 1.tabulā.

Otrais eksperiments: Spriegums $12 \mathrm{~V}$, māla nedaudz vairāk par smiltīm. Attālums starp elektrodiem $3 \mathrm{~cm}$. Eksperimenta ilgums 46 stundas. Šeit grunts sacietēšana notika daudz lēnāk nekā pirmajā eksperimetā. Tāpēc paraugi pa eksperimenta laiku tika svērti divas reizes (pirmā reize pēc 24 stundām), (skat.1. tabulā). Eksperimentu beidzot ap drāts elektrodi izvietoti jauktā veidā + ar -. Tāpēc tas paildzināja eksperimentu. Beidzot eksperimentu sakaltušais slānis ap drāts elektrodu $1,8 \mathrm{~cm}$, bet ap plati $2 \mathrm{~cm}$. Masas izmainas skatīt 1.tabulā.

1.tabula

Paraugu masas izmainas veiktajos eksperimentos

\begin{tabular}{|c|c|c|c|c|c|c|c|c|c|}
\hline \multicolumn{10}{|c|}{ Eksperiments } \\
\hline & \multicolumn{3}{|c|}{1} & \multicolumn{3}{|c|}{2} & \multicolumn{3}{|c|}{3} \\
\hline & plate & drāts & bezel. & plate & drāts & bez el. & plate & drāts & bez el. \\
\hline $\begin{array}{c}\text { Masa, g pirms } \\
\text { žävẽšanas }\end{array}$ & 252 & 248.2 & 267.2 & 102.7 & 104.4 & 124 & 134 & 62.25 & 82.25 \\
\hline $\begin{array}{c}\text { Masa, g pēc } \\
\text { Žārvēšanas }\end{array}$ & 227.5 & 222.5 & 229 & 92 & 95 & 108 & 123.15 & 57.5 & 77.25 \\
\hline $\begin{array}{l}\text { Masu starpíba, } \\
\%\end{array}$ & 9.72 & 10.4 & 14.3 & 10.4 & 9 & 12.9 & 8.1 & 7.6 & 6.1 \\
\hline $\begin{array}{l}\text { Masa, g pirms } \\
\text { žăvēšanas }\end{array}$ & & & & 140.7 & 100.35 & 124.5 & & & \\
\hline $\begin{array}{l}\text { Masa, g pēc } \\
\text { Žāuēšsanas }\end{array}$ & & & & 130 & 94.2 & 110.9 & & & \\
\hline $\begin{array}{l}\text { Masu starpība, } \\
\%\end{array}$ & & & & 7.6 & 6.1 & 10.9 & & & \\
\hline
\end{tabular}

Attăluma starp elektrodiem ie tekme uz sacietešanas diametru (eksp. veikts 24 stundas pie $24 \mathrm{~V}$ )

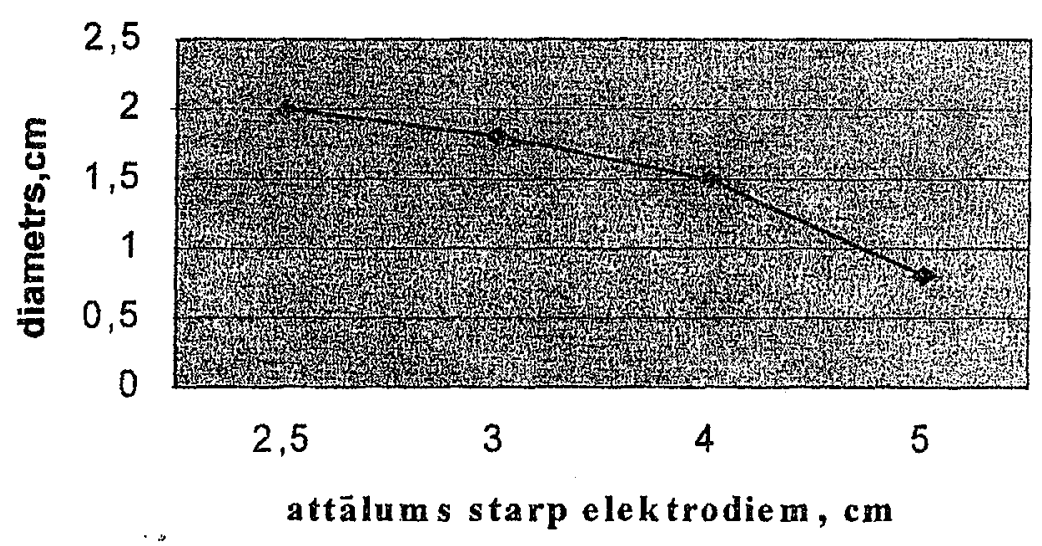




\section{Parauga mitruma izmaiṇa atka rîbā no ekspe rimenta ilguma}

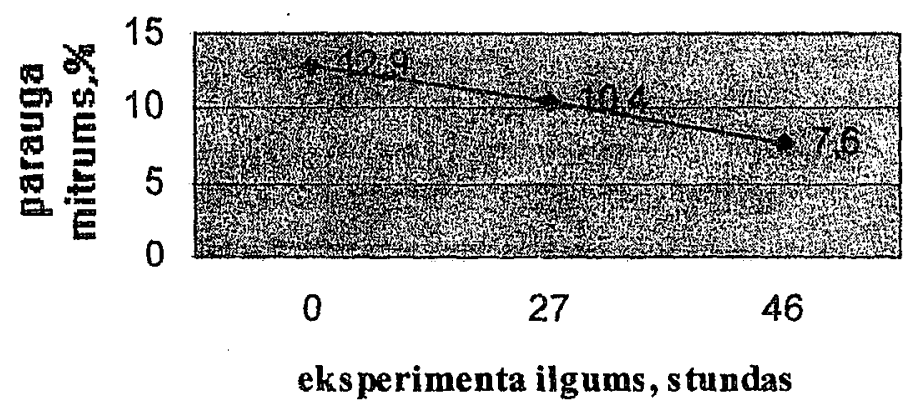

Elekroosmozes parădības pielietošana praksē

Elekrsoosmozes parādības pielieto tehnikā. Piemēram ar elektroosmozes palīdzỉbu veic daudz poraino materiālu (kūdra) žāvēšanu, kā arī pielieto hidrotehniskājăs iekārtās. Ar elektroosmozes palīdzību veic porainu materiālu, piem., koksnes piesūcināšanu ar dažādām ķīmiskajām vielām (antipirēni, antiseptikịi, ... ). Kāà arī ar elektroosmozes palīdzỉbu keramiskajā rūpniecỉbā ar drāts palídzỉbu, kura ir negatîvi lādēta, māla brusas griež ķiegelolos. Tãdā veidā nenotiek māla dạlinu pielipšana, tã kā šîs negatīvi lādētās dalinnas atgrūžas no drāts, kura negatīvi lādēta. Turpretĩ ūdens, kas satur pozitīvos jonus virzās uz drāti (elektrodu) un nodrošina tās labu iesmērēšanos.

Ľti plaši pielieto elektroosmozi grunts, kura draud nogrāt vai añ kāda grunts gabala, nostiprināšanai (skatît $2 . z \bar{m}$ ējumā). Tā ir salīđzinoši efektîva un neprasa lielus papildu lĩdzekḷus.

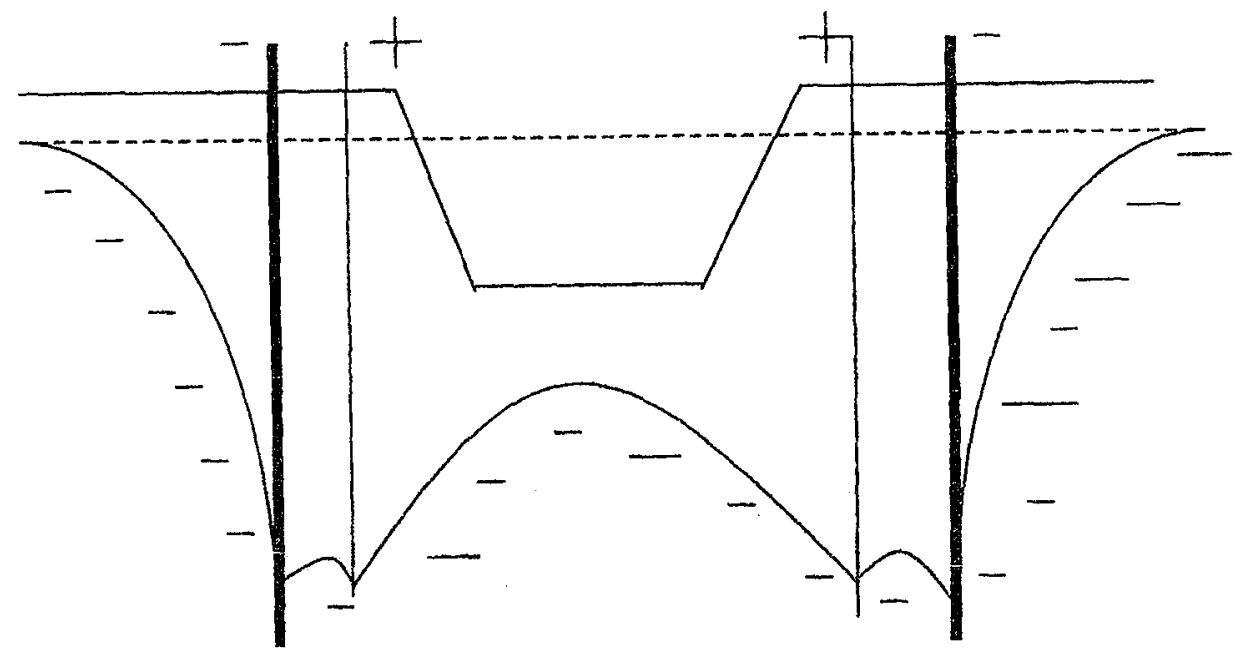

2.zīmējums. Elektroosmotiskā nosusināšana.

Elektroosmotisko nosusināšanu pielieto gruntīs, kur filtrācijas koeficients nav lielāks par $0,09 \mathrm{~m} /$ diennakțī. Parasti pielieto spriegumu $30-60 \mathrm{~V} .1 \mathrm{~m}^{3}$ grunts nosusināšanai vajag $5-40 \mathrm{KWh}$ elektroenerǵijas. Lai aizvadītu ūdeni no negatīvā 
elektroda, tas ir speciāls adatfiltrs, caur kuru izsūknē ūdeni prom. Adatfiltra diametrs 40 $50 \mathrm{~mm}$. Pozitivajam elektrodam izmanto metāla stieņus.

Ar elektroosmozes palīdzỉbu veic arī grunts cietināšanu. Šeit caur pozitivo elektrodu gruntī ievada cietinošu materiālu piemēram $\mathrm{NazSiO}_{3}$ un $\mathrm{CaCl} 2$. Šo metodi pielieto putekḷainās smiltīs, smilšmālā jeb tur, kur filtrācijas koeficients nav liels (Kf $<0,1)$, tas ir tur, kur ūdens savu spēku dẹl nefiltrējas cauri. Cietējošā viela līdz negatīvajam elektrodam nenonāk, jo pa ceļam sacietē. Ja gruntī ir sāļi (piem., dūṇas), tad elektrolīti nav vajadzīgi. Notiek - nosusināšana, apmaiņas reakcijas, elektrolīze, veidojas neatgriezeniski savienojami. Cietināšanas shëmu ar elektroosmozes palīdzību skatīt 3.zīmējumā.

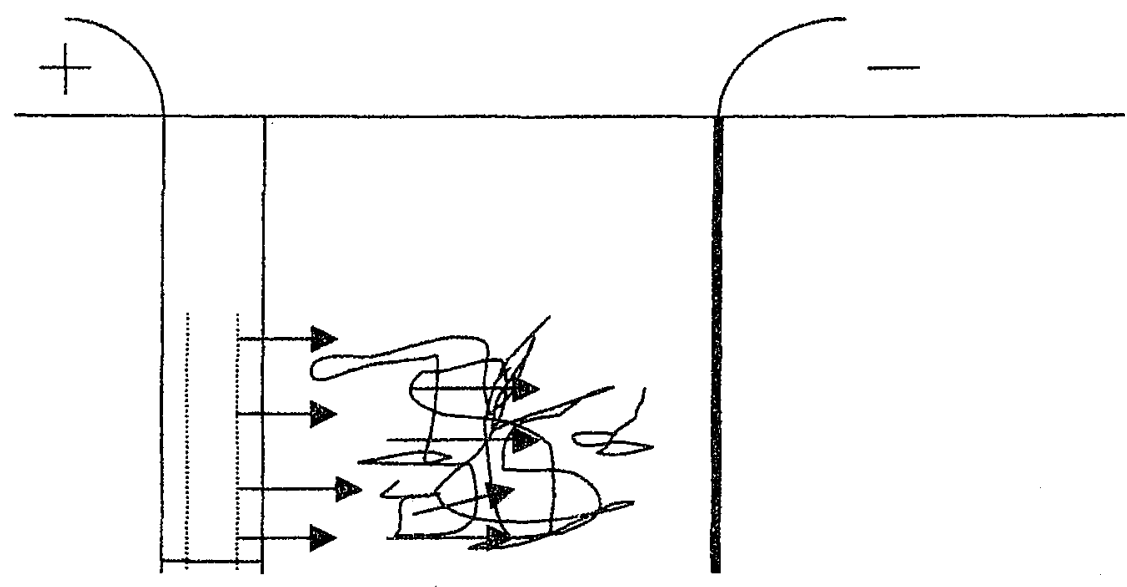

3.zīmējums. Elektroosmotiskās grunts cietināšanas shēma.

\section{Secinājumi}

Izejot no veiktajiem eksperimentiem, redzms, ka, jo tālāk atrodas elekrodi viens no otra, jo vajadzīgs ilgāks laiks, lai grunts sacietētu līdz noteiktai cietības pakāpei. Pie lielāka sprieguma grunts sacietěšanās notiek ātrāk nekā pie mazāka.

Būtiski grunts sacietēšanu ietekmẽ tieši māla daudzums tajā. Paraugi ar lielāku māla saturu sacietēja daudz ătrāk nekā tie, kuros bija mazāk.

Trešajā eksperimentā, kur elektrodi bija izvietoti jaukti pozitīvais ar negatīivo, vajadzēja vairāk laika, lai grunts sacietētu ap pozitivo elektrodu nekā pirmajos divos eksperimentos, kur elektrodu izvietojums bija paralēls viens otram.

Visos eksperimentos, kur tika pielietoti plates elektrodi grunts stiprināšanās notika lēnāk nekā pie dräts elektrodiem. 